\title{
Determinants of Formal Credit Repayment Performance by Smallholder Farmers in Dale Sedi Woreda
}

\author{
Bazezew Endalew \\ College of Business and Economics, Department of Economics, \\ Dambi Dollo University, Dambi Dollo, Ethiopia
}

\begin{abstract}
Ethiopian economy is mainly depends on agriculture which provides employment for $85 \%$ of the labor force and accounts for a little over 50 per cent of the GDP regardless of its low production potential. To bolster the sector, improvement of agricultural technologies with sufficient loan provision is advisable. However, smallholders are reluctant to repay again. This study therefore attempted to investigate the factors that affect smallholder farmers' formal credit repayment performance in Dale Sadie woreda. To do so, a microeconomic based analysis with multistage sampling technique (inclusion of both purposive and systematic random sampling) was used to determine the relevant sample size of the study. To analyze the data, both descriptive and inferential (Tobit regression) methods were utilized. The result of the study revealed that respondents' age, educational level, smallholder farmers of being protestant, orthodox, and Muslim religious followers, and loan repayment ratio were significantly and positively affect repayment performance, Moreover, farm households' family size and marital status of being widowed were statistically significant and has a negative impact on repayment performance. Therefore, responsible bodies should be involved to increase the repayment performance of small holder farmers.
\end{abstract}

Keywords: repayment performance, defaulters, Dale Sadie woreda, kebele

DOI: $10.7176 / \mathrm{JESD} / 12-17-01$

Publication date:September $30^{\text {th }} 2021$

\section{Introduction}

\subsection{Background of the Study}

The economy of Ethiopia is based mainly on agriculture which provides employment for $85 \%$ of the labor force and accounts for a little over 50 per cent of the GDP and about 90 per cent of export revenue (CSA, 2010). In spite of huge agricultural potential, the growth in agricultural production was insufficient to keep that of the demand. In fact, a higher and significant proportion of cultivated land is owned by subsistence farmers who produce about $97 \%$ of the national agricultural output (Wolday, 1999). The Ethiopian agriculture is mostly manifested by its very low productivity with grain yields reported for various crops varying between 5.1 and 9.6 quintals per hectare over the 1960/61-1991/92 period (Belay, 1998), but it shows some increment after 1990s(CSA, 2010).

In many African countries (from which Ethiopia is not unique to the region), major economic sectors are grouped under their infant stage of development for a long period of time, in Ethiopia, the agricultural sector has been unable to produce sufficient amount of output to meet the needs of the community, it is a type of subsistence in nature, from which many of the population were highly exposed for food insecurity and hanger (MoFED, 2008). Therefore, the improvement of the sector through adopting the system of intensification by increasing credit access to finance modern farming technologies or inputs like fertilizers, pesticides, and machineries is assumed to be a necessary condition (Zelalem et al., 2014).

However, the ratio of uncollected credit in the form of cash or in kind in most rural communities of Ethiopia is growing increasingly through time (MoFED, 2012), this was due to the fact that factors such as pessimistic view of the rural population towards credit leads to underutilization of the loan and faces repayment problem; lack of scientific studies on the relevance of fertilizers and chemicals for different soli types and weather conditions leads to low productivity, this results problem of repayment in a timely bases even farm households completely clear their existing livestock assets, consequently, it aggravates the problem of counter cycle of poverty over a dynamic period of time (Pinaki, 1998). The other likely reason for the low repayment ability of smallholder farmers in Ethiopia is due to the inherent nature of the sector as it is exposed for uncertainty and risk in the production of output and market integration, which results low returns to scale in the production process, and the absence of price- product market linkage increases the problem (Zelalem et al., 2014).

\subsection{Statement of the problem}

Credit provision is one of the principal components of rural development, which helps to attain rapid and sustainable growth of agriculture; rural credit is a temporary substitute for personal savings, which stimulates the process of agricultural production and productivity. To boost agricultural production and productivity farmers 
have to use improved agricultural technologies. However, the adoption of modern technologies is relatively expensive and smallholder farmers cannot afford to self-finance. As a result, the utilization of agricultural technologies is very low. It is argued that enhanced provision of rural credit would accelerate agricultural production and productivity (Briquette, 1999).

Although the government of Ethiopia is try to overcome the financial problem of adopting new farm technologies through providing formal credit services to smallholder farmers, they are likely to be defaulters. The probable reason is that credit is distributed without critically assessing the socio-economic condition of the community; rather it is highly reliant on the crud nature of strategies as well as agricultural package programs. The program is unable to scientifically review its applicability from the ground that the attitude of rural community towards credit matters (Hayimanot et al., 2016). This implies that, if credit institutions disbursed the loan to the community without conceptualizing or understanding for what purpose do the society receives the loan, they will become the loser because of the fact that the borrower are going to be defaulters (unable to repay the loan).

Therefore, some of the researchers utilized a binary logistic econometric model (the outcome variable is binomial in the sense that whether households are defaulter or not) (Firafis, 2015; Edet et al., 2014; and Ume S et al., 2018), but the default and non-default response of respondents may refer their habit or experience of repayment, implies it does not indicate the extent of repayment performance. To overcome this methodological gap, the researcher has been employed the tobit regression model by considering level of loan repayment conditional to explanatory variables, since it represents the extent of loan repayment performance of smallholder farmers (Abebe M, 2011). To the best of the researcher's knowledge, no research of the same type was conducted on the area. Therefore, assessing and investigating the determinants of this problem and establishing appropriate lending strategies so as to make the newly developed agricultural package program as efficient as possible through bolstering the repayment performance of borrowers is not a debatable issue in this uncertain world feature.

Accordingly, the general objective of this study was to investigate the determinants of formal credit repayment performance by smallholder farmers in Dale Sedi woreda.

The specific objectives of this study were:

$\checkmark$ To identify the impact of demographic factors on smallholder farmers credit repayment performance.

$\checkmark \quad$ To identify the effect of socio-economic factors on smallholder farmers' formal credit repayment performance.

$\checkmark \quad$ To investigate the effect of government training programs on smallholder farmers credit repayment performance.

$\checkmark \quad$ To assess the existing level of repaid loan on the area.

Following the above problems, the researcher was attempted to answer the following questions which were a simple extension of the specific objectives, thus:

$\checkmark$ What is the impact of demographic factors on smallholder farmers' formal credit repayment performance?

$\checkmark$ To what extent socio-economic factors impacts smallholder farmers formal credit repayment performance?

$\checkmark$ What is the effect of government training programs on smallholder farmers' credit repayment performance?

$\checkmark \quad$ What does the existing level of smallholders loan repayment experience looks like?

\section{Methodology of the Study}

\subsection{Description of the Study Area}

Dale Sadi is one of the woredas in the Oromia Region of Ethiopia, it is part of the Kellem Welega Zone. Dale Sadi is bordered on the south by the Illubabor Zone, on the west by Dale Wabera, on the north by Mirab Welega Zone, and on the east by Lalo Kile. The administrative center of this woreda is Haro Sebu and it is far from Addis Ababa by about 549 kilo meter in the western direction and its distance is about 87 kilo meter from Dambi Dollo, the capital of kellem wollega zone. Dale Sedi was separated from former Dale Laloworeda (AODW, 2011). The 2007 national census reported a total population for this woreda of 74,039, of whom 36,752 were men and 37,287 were women; 4,721 or $6.38 \%$ of its population were urban dwellers. In addition, the report also recognized the number of households is about 13139 . The majority of the inhabitants were Protestants, with $56.29 \%$ reporting that as their religion, while $25.56 \%$ observed Islam, and $17.99 \%$ observed Ethiopian Orthodox Christianity.

\subsection{Data Source and Type}

The data used for this study was extracted from both primary and secondary sources. Here, the nature of the data 
is cross-sectional type which consists of both quantitative and qualitative information mainly from individual bases, for the primary data, the researcher was employed both open and closed ended questionnaire, focus group discussion and structured interview. The secondary data was obtained from journals, internets, and from concerned institutions (e.g. Oromia Saving and Credit Institutions, and Woredas Agricultural Office).

Accordingly, before obtaining the sample households in each kebele, we were forced to determine the total sample size of the study. To do so, most studies used a simplified formula provided by Yamane (1967) that used to determine the required sample size at $95 \%$ confidence level and 5\% level of precision and it is given by:

$$
\mathrm{n}=\frac{N}{1+N(e) 2}=\frac{3973}{1+3973(0.05) 2}=364 ; \text { Where, } \mathrm{n} \text { is the total sample size of the study }
$$

$\mathrm{N}=3973$, it is the size of the total household population of the sampling unit (in 7 kebeles);

$\mathrm{e}=5 \%(0.05)$, acceptable error, the precision or marginal error between the sample and the population which is mostly applicable in social science research. Thus, the number of sample households from each sample kebeles can be determined through stratification as proportional as possible and it is indicated below.

\section{Table 1. 1 Total numbers of farm households in each kebeles ${ }^{1}$}

\begin{tabular}{ccc}
\hline \hline Name of kebeles & Total Household & Sample Household \\
\hline Gonsi dereba & 329 & 30 \\
Gute anani & 627 & 57 \\
Satano Dima & 712 & 65 \\
Arere Chole & 578 & 53 \\
Jarso Ajabul & 804 & 74 \\
Arere Tulu & 573 & 53 \\
Awetu Gendaso & 350 & 32 \\
\hline \multicolumn{4}{c}{ Total } & $\mathbf{3 9 7 3}$ & \\
\hline \hline
\end{tabular}

\subsection{Sampling Technique and Sample Size}

To determine the relevant sample size of the study, the researcher adopted multi stage sampling technique. At the first stage, due to the heterogeneous characteristics of the population as reported by Oromia Saving and Credit institutions in (2018), the researcher purposively choose Dale Sadi woreda as a case study. In the second stage, by applying simple random sampling technique, out of twenty seven (27) kebeles in the woreda, the researcher randomly selects seven (7) numbers of kebeles as a sampling unit, provided that the randomly selected kebeles has a total household of 3973 (target population). In the third stage, as we can see from table 1.1 below, the sample households from the selected sample kebeles are derived as proportional as possible.

\subsection{Methods of Data Collection}

The main source of data for this study was collected from primary data source through self-designed questionnaire of both closed and open ended type, a systematic and well-structured interview process with the help of highly standardized technique of recording has been utilized. The other important source of data employed in this study was the secondary one, and it has been gathered from various written and unwritten sources such as, internal reports, internets, published and unpublished documents, and other written literatures related to the inquiry.

\subsection{Methods of Data Analysis}

To analyze the data, the researcher was employed both descriptive and inferential approach. For the descriptive aspect, simple statistical tools such as, proportions, measure of central tendencies and measure of dispersion along with various data presentation tools (tables and graphs). In addition to the descriptive approach of data analysis, an econometric (inferential) analysis of data along with appropriate testing mechanisms was addressed. Therefore, the researcher have had an attempt to conduct basic diagnostic tests such as goodness of fit, hetroscedasticity, multicolinearity, normality, and specification tests so as to make the analysis as efficient as possible. To conduct this analysis, relevant soft-ware packages (eg, STATA) were employed as a tool of analysis.

\subsection{Econometric Model Formulation}

To run the inferential analysis, the researcher was utilized Tobit regression models extensively so as to address the problem in an appropriate manner.

\footnotetext{
${ }^{1}$ Kebeles are the Ethiopian version of describing a certain districts for administrative purpose.
} 


\subsubsection{Functional Specification of the Tobit Model}

The Tobit regression model, an econometric model applied when the outcome variable is often a censored or truncated type (Verbeek, 2004). The main rationale behind here is that the dependent variable was found to be partly discrete and partly continuous. It is discrete in terms of the two groups of farm households (those who are defaulters and non-defaulters); it is continuous in terms of the level of repayment of the non-defaulters. Here, one measure important thing what we should bear in mind is that the outcome variable of default and non-default reaction/ response of the respondents may refer their habit or experience of repayment, it could not be able to actually measure the extent at which their repayment performance conditional to explanatory variables is accounted for, since we are dealing with repayment performance. That is why we preferred the tobit model than the logistic model of analysis because of the fact that the continuous segment of repayment amount actually measures repayment performance, unlike the logistic model which considers the mere nature of being defaulter or not (Abebe M, 2011). Accordingly, the model can be specified as:

$Y i=\beta_{1}+\beta_{2} x_{i}+\mathrm{u}_{\mathrm{i}}$, where $\mathrm{u}_{\mathrm{i}}$ is NID $(0$, constant variance, $) 0$

Yi represents the censored dependent variable; econometrically it can be defined as;

$y_{i}=\left\{\begin{array}{cc}L & \text { if } y * \leq 0 \\ y *=\beta_{1}+\beta_{2} x_{i}+u i: & \text { if } L<y *<U \\ U & \text { if } y * \geq U\end{array}\right\}$;Where, $\mathrm{L}$, refers lower limit; $\mathrm{U}$, refers upper limit;

Yi represents the dependent variable of repayment amount. The value of the response variable (Yi) is found in the range of $0 \leq y i \leq u$. Therefore, the tobit model yields the extent of repayment between borrowers and it is likely to measure the degree of repayment performance.

Table 1.2 Factors which are assumed to affect loan repayment performance of small holder farmers

\begin{tabular}{|c|c|c|c|}
\hline \multirow{3}{*}{$\begin{array}{l}\text { variable } \\
\text { repayment level(dependent) } \\
\text { age }\end{array}$} & nature of variables & description & expected relationship \\
\hline & continuous but cens & & \\
\hline & continuous & age of sample farm households & positive \\
\hline marital status & nominal & $\begin{array}{l}\text { 1: married } \\
\text { 2: single } \\
\text { 3: widowed } \\
\text { 4: divorced }\end{array}$ & $\begin{array}{l}\text { positive } \\
\text { for sing } \\
\text { and } \\
\text { married }\end{array}$ \\
\hline Sex of households & dummy & $\begin{array}{l}1: \text { male } \\
0: \text { female }\end{array}$ & $\begin{array}{l}\text { positive } \\
\text { for male }\end{array}$ \\
\hline educational level & continuous & continuous & positive \\
\hline family size & continuous & continuous & positive \\
\hline religion & nominal & $\begin{array}{l}1: \text { protestants } \\
0: \text { otherwise }\end{array}$ & indeterminate \\
\hline
\end{tabular}

\begin{tabular}{|c|c|c|c|}
\hline farm land owned & continuous & land in hectare & positive \\
\hline livestock owned & continuous & size of livestock & positive \\
\hline extension service & dummy & $\begin{array}{l}\text { 1: who take extension } \\
0: \text { otherwise }\end{array}$ & $\begin{array}{c}\text { negative for non- } \\
\text { participant }\end{array}$ \\
\hline non-farm income & continuous & income from non-farm activities & positive \\
\hline on-farm income & continuous & income from non-farm activities & positive \\
\hline amount of fertilizer used & continuous & fertilizer used in $\mathrm{kg}$ & positive impact \\
\hline saving habit & dummy & $\begin{array}{l}1: \text { if they save } \\
0: \text { otherwise }\end{array}$ & negative if no saving \\
\hline
\end{tabular}

member of cooperatives dummy




\section{Results and Discussion}

\subsection{Descriptive Results of the Study}

As we can observe from the survey results of table 1.3 (left censored part), out of the total 364 observations , 55 $(15 \%)$ of them were not in a position to repay their loan in a timely manner, however, the remaining $85 \%$ of the sample respondents were try to repay their loan. The average monthly farm income of the sample respondents in the study area was about birr 2,663.9, it is by far more than the respective non-farm income size of smallholder farmers which was about birr 389.15 inclusion of those who has not any non-farm income sources. This is an indication of the low involvement of smallholder farmers in non-farm activities. The mean age of respondents is about 34.7, with a minimum and maximum age of 18 and 61 years respectively. Here, one can understand that the sample respondents are categorized under the economically active age group, this might be the reason why the relative proportion of defaulters (nonpayers) are comparatively lower than that of non-defaulters, because of the fact that as households are grouped under the working age category, they are expected to be more productive and responsive to adopt new way of production system, they can be able to generate more income, as a result, they can easily repay their loan timely. The average educational level of sample farm households is about grade two with a minimum and maximum grade levels of zero and grade twelve completers respectively. The average family size of sample farm households is about 3.6 along with an average of 1.4 numbers of dependents per sample populations; the maximum level of the economically inactive population (dependents) is four (4) which is less than by more than half of that of the maximum levels of family size.

Table 1. 3 Summary of Descriptive Statistics

\section{Variables}

\section{Mean standard}

deviation Minimum Maximum

average monthly farm income

age of households

educational level of farm households

numbers of family size

number of dependents

fertilizers used in kuntal

land size in hectare

number of livestock

average monthly non-farm income

size of loan in birr

amount of loan repaid

loan repayment ratio

$\begin{array}{llll}2663.926 & 1214.463 & 900 & 6000\end{array}$

$\begin{array}{llll}34.78022 & 10.63914 & 18 & 61\end{array}$

$\begin{array}{llll}2.005495 & 2.53569 & 0 & 12\end{array}$

$\begin{array}{llll}3.659341 & 2.157541 & 1 & 9\end{array}$

$\begin{array}{lllll}1.423077 & 1.190928 & 0 & 4\end{array}$

$\begin{array}{llll}2.60989 & 1.169639 & 1 & 5\end{array}$

$\begin{array}{llll}1.956044 & 1.722719 & 0 & 9\end{array}$

$\begin{array}{llll}5.756906 & 2.848243 & 1 & 15\end{array}$

$\begin{array}{llll}389.1484 & 262.0361 & 0 & 1000\end{array}$

$\begin{array}{llll}23967.03 & 10612.07 & 3000 & 50000\end{array}$

$\begin{array}{llll}19071.43 & 12585.81 & 0 & 50000\end{array}$

Source: own computation from survey data, 2019.

\subsubsection{Descriptive Results of Some Categorical Variables}

This study incorporates some demographic variables with other socio-economic variables as a factor affecting small holder farmers' credit repayment performance. Therefore, as we can observe from table 1.4 below, $53 \%$ of the sample respondents are males and the remaining of them (47\%) are females. Moreover, from the total 364 sample respondents, about $104(28.5 \%)$ of them are married households and the other $25.5 \%, 24.4 \%$, and $21.7 \%$ of them are single, widowed, and divorced respectively.

Table 1.4 Description of categorical variables

\begin{tabular}{|l|lcc|}
\hline \multicolumn{1}{|l|}{ Variables } & \multicolumn{2}{c|}{ frequency } & percentage \\
\hline \multirow{3}{*}{ Sex } & Male & 196 & 53 \\
\cline { 2 - 4 } & Female & 168 & 47 \\
\hline \multirow{3}{*}{ Religion } & Married & 104 & 28.5 \\
\cline { 2 - 4 } & Single & 93 & 25.4 \\
\cline { 2 - 4 } & Widowed & 90 & 24.3 \\
\cline { 2 - 4 } & Divorced & 77 & 21.7 \\
\hline \multirow{3}{*}{$\begin{array}{c}\text { Participation in } \\
\text { training programs }\end{array}$} & Protestant & 165 & 46 \\
\cline { 2 - 4 } & Orthodox & 100 & 27.5 \\
\cline { 2 - 4 } & Muslim & 70 & 19.2 \\
\cline { 2 - 4 } & Other & 29 & 7.2 \\
\hline \multirow{2}{*}{ Sourticipant } & 251 & 68.9 \\
\hline
\end{tabular}

Source: own computation from survey data, 2019. 
From sample respondents' religious point of view, majority (46\%) of them are protestant religion followers, followed by orthodox, Muslim, and other religious followers which represents about 27.5\%, 19.2\%, and 7.2 respectively. On the other hand, the researcher undertake the involvement of smallholder-farm households on government training programs and other extension services as a factor affecting their credit repayment performance, as a result, $68.9 \%$ of the sample respondents are active participants, whereas the remaining $31 \%$ of them are not in a position to take part in various training programs, their main reason was due to lack of transport services, unwillingness to participate because of expectation of irrelevant information and existence of inefficient government reports on the area.

\subsubsection{Extents of Repayment Performance between Participants and non-participants in Government} Training Programs.

To verify whether there is significant difference in average repayment performance between those smallholder farmers who are participated in government training programs and who are not, an independent sample t-test technique was utilized here. Thus, a sample of 100 households (50 of participants and 50 of non-participants) are randomly taken from the already working samples of 364 farm households' for estimation purpose. To run this analysis, a simple hypothesis is developed here, such that;

$\mathbf{H}_{0}$ : The average repayment ratio of participants is less than or equal to that of non-participants.

$\mathbf{H}_{1}$ : The average repayment ratio of participants is greater than or equal to that of non-participants.

Accordingly, from the survey results of table 1.5, one can understand that our null hypothesis is failed to be accepted, since the p-value of 0.013 (at 1-tailed) is less than that of the significance level (0.05). Therefore, we can accept the alternative hypothesis states that the repayment ratio of participants is greater than or equal to that of non-participants, here from table below, the mean repayment ratio of participants is about 0.729 , while that of non-participants is about 0.54 , which is less than the repayment ratio of the former.

Table 1.5 Group statistics of repayment performance between participants and non- participants

\begin{tabular}{|l|l|l|l|l|}
\hline Groups of farm households & Mean & Standard deviation & Number of observation & Sig (at 1-tailed) \\
\hline Participant & 0.729 & 0.3635 & 50 & \multirow{2}{*}{0.013} \\
\cline { 1 - 4 } Non-participant & 0.540 & 0.4050 & 50 & \\
\hline
\end{tabular}

Source: own computation from survey data 2019.

We can also prove that the variation (standard deviation) of the average repayment ratio between participant smallholder farm households is less than that of the variation in the average repayment ratio of non-participants. This is an indication of the more probability of consistency in repayment ratio of smallholder farmers if they are actively involved in government training programs. The likely reason according to the respondents was that involvement in training programs increase their efficiency of loan utilization, particularly the way how they are going to use the loan, that is creating awareness on the type of investment that the loan must be allocated, the extent of profitability, analyzing the risk and return characteristics of assets and the like.

\subsubsection{Trends of Smallholder Farmers Credit Repayment Performance.}

To understand trends of small farm households' credit repayment performance in the study area, the researcher was try to examine how it is looks like (whether it is increasing, decreasing, or stagnant) for the last five years up to now, it is just a matter of degree! Due to the cross-sectional nature of the data set. Therefore, the overall figure of the data set as indicated in figure 1.1 shows that majority of sample respondents experiences lower repayment performance for the last five years up to now due to high price of commodity, existence of group loan system, stagnant level of income, existence of unforeseen events, high interest rate, use of more addictive stimulants, and increased in family size. In addition to this, part of the respondents confirms that their repayment performance was increasing to some extent due to proper allocation of loan, investment in less risky assets, existence of nonfarm income sources and so on. The higher proportion of male respondents on the bar chart in all categories of trend characteristics is probably due to the existence of high male sample respondents (see table 1.4 above). 


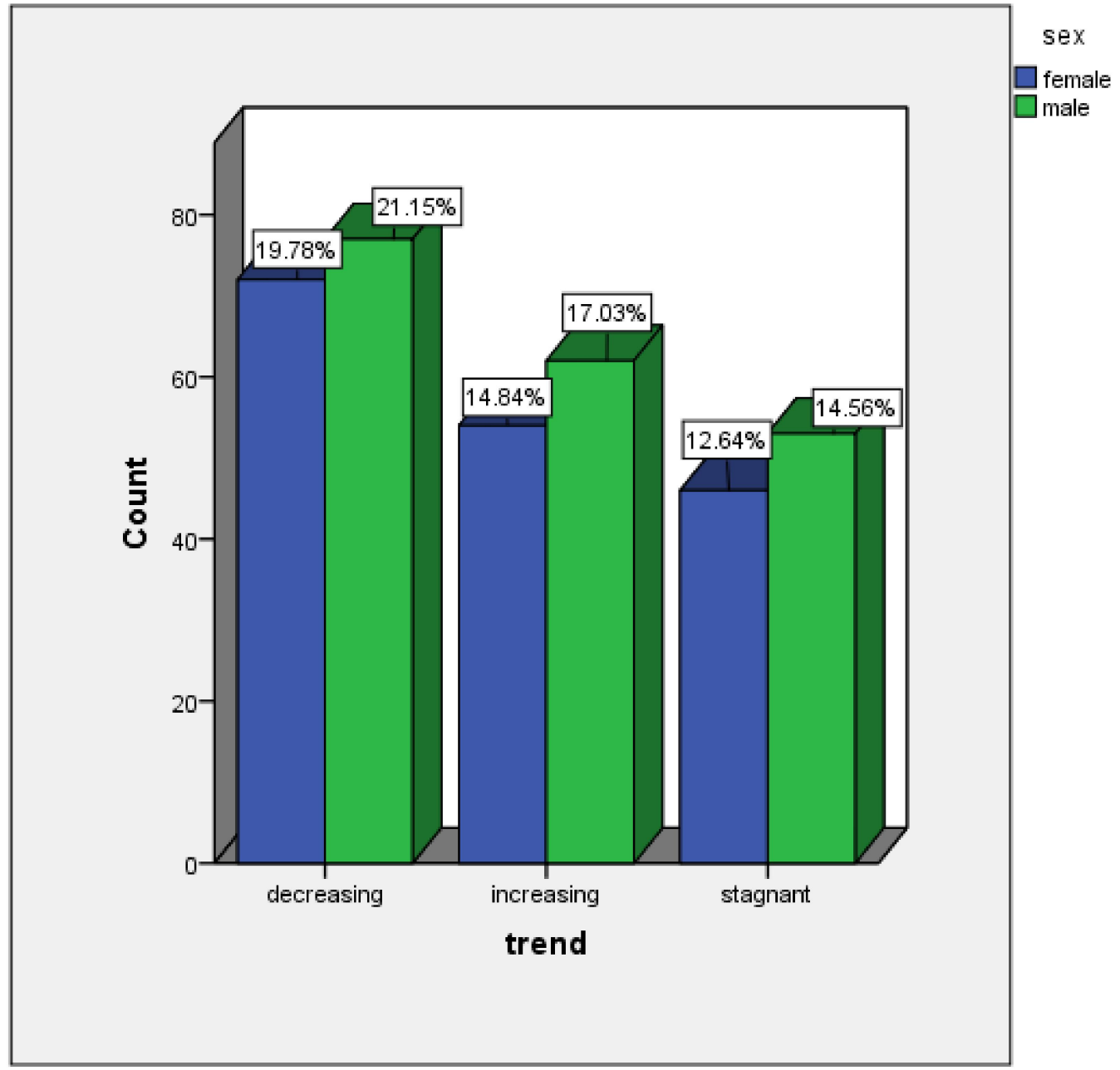

Figure 1.1 trends of repayment performance

\subsection{Econometric Results}

\subsubsection{Determinants of small holder farmers' formal credit repayment performance}

This section primarily covers the econometric (inferential) results of the study which aims to investigate the likely factors that affect smallholder farmers' formal credit repayment performance in Dale Sadie woreda. So that, an econometric model of tobit regression was employed as a tool of analysis. Therefore, as we can observe from table 1.6, a total of 364 sample households were undertaken. The possible factors utilized in the study were jointly significant to affect households saving capacity at $1 \%$ level of significant (prob $>$ chi $2=0.000$ ). 
Table 1.6 Tobit estimates of small holder farmers' formal credit repayment performance

\begin{tabular}{|c|c|c|c|c|}
\hline \multirow[b]{2}{*}{ Variables (constraints) } & \multicolumn{2}{|c|}{$\begin{array}{l}\text { Case(I): } \\
\text { Tobit estimates (robust } \\
\text { regression) }\end{array}$} & \multicolumn{2}{|c|}{$\begin{array}{l}\text { Case (II): the marginal } \\
\text { effect after Tobit (robust regression) }\end{array}$} \\
\hline & Coefficients & $\begin{array}{l}\text { Standard } \\
\text { error }\end{array}$ & Coefficients & Standard error \\
\hline Monthly farm income & .3388143 & .5138125 & .3388143 & .51381 \\
\hline Age & $92.96398 * * *$ & 53.98677 & $92.96398 * * *$ & 53.98677 \\
\hline Educational level & $389.2012 * * *$ & 224.2443 & $389.2012 * * *$ & 224.24 \\
\hline Number of family size & $-644.9134 * * *$ & 339.2455 & $-644.9134 * * *$ & 339.25 \\
\hline Sex of being female (dummy2) & 665.5142 & 1198.279 & 665.5142 & 1198.3 \\
\hline Protestant (dummy1) & $6527.27 *$ & 1685.285 & $6527.27 *$ & 1685.3 \\
\hline Orthodox(dummy2) & $8767.083 *$ & 1927.618 & $8767.083^{*}$ & 1927.6 \\
\hline Muslim(dummy3) & $6872.919 *$ & 1964.185 & $6872.919 *$ & 1964.2 \\
\hline Married(dumy1) & -79.54369 & 1725.421 & -79.54369 & 1725.4 \\
\hline Single(dummy2) & -720.6857 & 2018.385 & -720.6857 & 2018.4 \\
\hline Widowed (dummy3) & $-3402.069 * *$ & 1715.27 & $-3402.069 * *$ & 1715.3 \\
\hline Land size in hectare & -24.67183 & 349.585 & -24.67183 & 349.585 \\
\hline Numbers of livestock owned & 26.81431 & 213.4307 & 26.81431 & 213.4307 \\
\hline Monthly Non-farm income & .3050609 & 2.284709 & .3050609 & 2.28471 \\
\hline Fertilizer used in quintal & -345.5504 & 534.9585 & -345.5504 & 534.96 \\
\hline 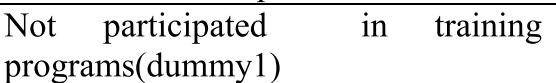 & -858.0913 & 1270.825 & -858.0913 & 1270.8 \\
\hline Loan repayment ratio & $3677.34^{*}$ & 1908.594 & $3677.34 *$ & 1908.6 \\
\hline Constants & $-19466.63 *$ & 4874.402 & & \\
\hline
\end{tabular}

$*=$ significant at $1 \% ; * *=$ significant at $5 \% ; \quad * * * 10 \%$

Log likelihood $=-3186.3084 ; \operatorname{LR}_{c h i}{ }^{2}(17)=389.58$

; prob $>c h i^{2}=0.0000 ;$ pseudo $R^{2}=$

55 left-censored observations at payed $<=0$

298 uncensored observation

11 right-censored observations at payed $>=50000$

Source: own computation from survey data, 2019.

From individual significance test point of view, sample respondents age, educational level, and numbers of family size were statistically significant at $10 \%$ level of significance. Moreover, smallholder farmers of being protestant, orthodox, and muslim religious followers, loan repayment ratio (loan repaid per borrowed), and the constant term were found to be statistically significant at $1 \%$ level of significance, and the marital status of being widowed was statistically significant at $5 \%$ level of significance.

\subsubsection{Testing OLS Assumptions}

Hetroscedasticity Test: To verify whether the estimated values of the regression results are efficient and reliable for interpretation, it is crucial to verify the usual OLS assumptions (Verbeek, 2004). Therefore, the conditional distribution of stochastic terms conditional to the regression matrix should have zero mean and constant variance (homoscedastic). Therefore, the study employed the Breusch Pagan/Cook-Weisberg test for hetroscedasticity, and it confirms the existence of hetroscedasticity problem, because we are failed to accept the null hypothesis of constant variance at a 5\% significance level. However, we can solve the problem through running of robust regression.

Mullicolinearity Test: This problem arises when there is significant association among independent variables incorporated in a given econometric model; it yields an inefficient and biased estimator of the sample parameters (Verbeek, 2004). Therefore, the study used the variance inflation factor (VIF) as a checking mechanism for continuous variables and pairwise correlation (contingency test) for the discrete case. So that, the mean Variance Inflation Factor (VIF) of continuous variables in this model was about 1.02, which is less than ten-the standard and recommended estimated value of mullticollinearity test (Gujarati N, 2004). The correlation coefficient between each categorical variable is below 0.8 , therefore, it confirms no multicollinearity problem.

Specification Test: To verify the nature specification, the researcher has been applied the Ramsey RESET test technique of omitted variable problem, as a result, we have the hypothesis that: $H_{o}$ : Model has no omitted variables

$F(3,341)=2.63 ;$ Prob $>F=0.0501$. Therefore, the $p$-value of $0.0501>0.05$ (sig level), we are failed to reject the null hypothesis, implies that the model is correctly specified. 
To identify the degree or the extent at which each significant variable affects the credit repayment performance of smallholder farmer's, it is advisable to drive the marginal effect after tobit estimate (Verbeek, 2004). As we can observe from table 1.6 above, smallholder farmers age positively and significantly affects their credit repayment performance at $10 \%$ level of significance, that is ceteris paribus, as age increases by one year, on average, smallholder farmers' credit repayment performance increases by birr 92.7 , the possible reason is that as age increases smallholder farmers are in a position to understand the importance of credit and the way how they are going to utilize it significantly, they are expected to know the risk and return characteristics of assets and they are also able to understand and conceptualize the value of government training programs on this issue (Abebe, 2011). This finding is consistent with the findings of Foltz (2004) who revealed that age was a significant and positive determinant of farm households' repayment performance. However, the logistic results of (Ume et al., 2018) found out that households' age is found to be a significant determinant of loan repayment performance negatively at 5\% significance level; it affects the probability of farmers' repayment performance by about $4.6 \%$

Smallholder farmers' educational level positively and significantly affects their repayment performance at $10 \%$ level of significance. Ceteris paribus, as farm households educational level increases by one year, their repayment performance increases by birr 389.20. The probable reason is that most of the time education and training programs are expected to enhance farmers' capability and skills to acknowledge and comprehend technological innovations in various economic activities which lead to improved and sustainable agricultural productions and they are more aware of agricultural marketing, as a result, they can able to generate more profit and repay their loan in a timely manner. Educated households are also aware of the fact that loan provided to them is their national resource collected in the form of tax from themselves for the purpose of bolstering their income level, as a result, they are going to be non-defaulters (Girma , 2008), this is also compatible with the findings of (Diagne, 1999) who found out that educational level have a positive and significant (5\%) impact for farm households to be non-defaulter. On the other hand, there is one counter argument from the findings of Belay (1998) who found out that the preference of educated farm households mostly prefer "white collar job" as against farming, will result low loan repayment performance, since a substantial amount of loan could be diverted to non-agricultural activities that may not be viable enough to generate the necessary dividends to repay the loan easily.

The other variable significantly $(10 \%$ level of significant) and negatively affects smallholders' loan repayment performance is family size of households. Therefore, ceteris paribus, as small farm households' family size increases, on average, their repayment performance decreases by birr 644.9134 , this is because as the number of family size increases, the extra cost that a given farm household spends for his or her children in the form of educational costs, medical costs, transportation costs, costs for food, and other related costs increases overtime, this hinders a farm household to repay his/her loan in a timely base. The other significant and positive determinant of small farm households credit repayment performance is their religion (being protestant, orthodox, and Muslim) at 1\% significance level, accordingly, the study undertake other religious followers (eg catholic and the like) as a reference group, therefore, ceteris paribus, being protestant followers have the capability to repay their loan compared to other religious followers by more than birr $6,527.27$, similarly, being orthodox and Muslim religious followers have the capacity to repay their loan compared to other religious followers by more than birr 8, 767.08 and birr 6, 872.9 respectively. However, the logistic results of (Ume et al., 2018) showed that households religion were not a significant determinant of credit repayment performance.

The study was incorporated households marital status as a nominal variable and considers marital status of being divorced as a bench mark group, as a result, marital status of being widowed was found to be statistically significant at 5\% level of significance, whereas marital status of being single and married was not a statistical determinant of credit repayment performance. Therefore, being widowed farm households have the possibility to repay their loan by less than birr 3402.069 compared to that of divorced. The possible reason is that divorced households are legally permitted to be free from repaying the loan, and also they are likely to be exposed for economical and psychological risk, this significantly affects their motivation and involvement in income generating activities, then they are going to be loan defaulters. ${ }^{1}$ This finding is supported by the findings of (Brehanu and Fufa, 2008) explored that widowed households are less likely to be non-defaulter compared to married households.

To examine the extent at which the loan size of smallholder farmers affects their repayment performance, we incorporate loan repayment ratio as a proxy of loan size and explored that loan repayment ratio positively and significantly affects repayment performance at $1 \%$ level of significance. Ceteris paribus, as loan repayment ratio increases by one unit, on average, the level of repayment is increased by 3677.34 , this is indirectly an indication of the existence of positive relationship between loan size and repayment ratio, because repayment ratio is the ratio of loan repaid per borrowed. The likely reason is due to the fact that as farm households borrow large

\footnotetext{
${ }^{1}$ Defaulters imply those who are reluctant to repay the loan.
} 
amounts of money from institutions, they can be able to invest more in different forms of assets; this could reduce risks which can be created by natural and human made factors "law of large number" This is consistent with the findings of (Girma, 2018) revealed that loan size received by borrowers positively and significantly affects the probability of being non-defaulters at 1\% significant level, whereas (Hayimanot et al., 2016) revealed the insignificant effect of loan size on farm households repayment performance.

\section{Conclusions and Recommendations \\ 4.1 Conclusions}

The economy of Ethiopia is based mainly on agriculture which provides employment for $85 \%$ of the labor force and accounts for a little over 50 per cent of the GDP and about 90 per cent of export revenue (CSA, 2010). In spite of huge agricultural potential, the growth in agricultural production has not been able to keep pace with that of the demand. Therefore, to overcome this problem, the involvement of formal financial institutions in the rural community to finance agricultural inputs is an invaluable issue; this is because large agricultural projects could not be efficiently utilized and productive by farmers from their own fund. However, small farm households could not be able to repay the loan in a timely manner, this creates imbalances in government financial institutions and frequently retard large government investment projects in Ethiopia in general and Oromia region in particular (Brehanu and Fufa, 2008).

Therefore, this study have had an attempt to investigate the major determinants that affect smallholder farmers formal credit repayment performance in consideration of Dale Sadie woreda as a case study, Kellem Wollega Zone, Oromia region, Ethiopia. The study was utilized the multi stage sampling technique of considering Dale Sadie woreda as a case study, and about seven numbers of kebeles were randomly selected as a sampling unit from the total twenty seven numbers of kebeles, and finally by using yemane formula (Yemane, 1967) 364 sample farm households were selected as a sample respondent. The study was utilized an extension of the limited dependent variable model or the tobit regression model, due to the nature of the dependent variable amount of repayment from the entire borrowed capital, here, there are many censored (zero) values of the response variable because of there are farm households who are not repay the borrowed capital and the one who are not borrowed at all.

The descriptive results of this study shows that about $15 \%$ of the respondents was not repay their loan due to increment in price of goods and services, existence of unforeseen events, existence of group-borrowing. On the other hand, the remaining $85 \%$ of the respondents were in a position to repay their loan; hence, it shows good repayment performance. The average loan size of the area according to the survey results of the study was birr 23,967.03, while the average repayment amount and its repayment ratio was birr 19,071.43, and 0.79 respectively. Moreover, the study revealed that the mean repayment ratio of smallholder farmers who are involved in training programs are significantly experiences high average repayment ratio (0.729) than those who are no involved (0.540). From trends of repayment point of view for the last five years, many number of farm households experience decreasing repayment tradition in their five years credit experience followed by increasing and stagnant responses (see figure 1.1).

Explanatory variables were jointly significant at $1 \%$ level $\left(\right.$ prob $\left.>c h i^{2}=0.0000\right)$ of significance, this result shows how the model is well-fitted. From individual significance point of view, sample respondents age, educational level, and numbers of family size were statistically significant at $10 \%$ level of significance. In addition, smallholder farmers of being protestant, orthodox, and Muslim religious followers, loan repayment ratio (loan repaid per borrowed), and the constant term were found to be statistically significant at $1 \%$ level of significance, and the marital status of being widowed was statistically significant at $5 \%$ level of significance. However, the possible determinants such as monthly levels of farm income, sex of households, marital status of being married and single, levels of land size in hectare, numbers of livestock owned, monthly non-farm income, fertilizers used in quintal, and participation in training activities were not found to be statistically significant.

\subsection{Recommendations}

The following possible generalizations or recommendations were derived as the best policy implication following the findings of this survey study, these are:

$\checkmark$ According to the findings of this study, smallholder farm households educational level were found to be a positive and significant determinant of their credit repayment performance, therefore, well-designed educational system should be designed so as to bolster the income generating capacity of farmers as well as improving their credit repayment performance.

$\checkmark$ In similar manner, government agricultural extension programs conducted on the area creates significant difference in credit repayment performance between training participants and nonparticipants, therefore, the responsible body should be able to address the program as much as possible through employing well- trained personnel at the grass root level about the purpose of training as well as how they are going to invest. 
$\checkmark \quad$ The government should be in a position to monitor or take in to account the issue of family planning and age structure at the time of loan provision, since it has a significant effect on their credit repayment performance, for instance, providing training on the issue of loan allocation at different age structure, and also it is advisable to focus on family planning programs if sustainable change is required.

$\checkmark$ Financial institutions should consider the loan size provided to farm households and the system of provision or service delivery approach, as the survey result confirms that when the loan is provided in group, then one or more of the members are reluctant to repay the credit, this results difficulty in creditprofitability linkage.

\section{Reference}

Abebe, M. (2011). Determinants of Credit Repayment and Fertilizer use by Cooperative members in Ada District, Oromiya Region, Ethiopia.

Belay, K. ( 1998). Structural problem of peasant agriculture in Ethiopia. Research report. Alemaya university of agriculture, Ethiopia.

Berhanu, A., Fufa B. (2008). Repayment rate of loans from semi-formal financial institution among small-scale farmers in Ethiopia. Two-limit Tobit analysis. J.soc.Econ. 37:2221-2230.

Briquette. (1999). Better practices in Agricultural lending, FA publication.

CSA, 2010. Statistical abstract. Various issues. Addis Ababa, Ethiopia.

Diagne, A., Chimombo, W., Simtowe, F., \& Mataya, C. (2000). Designand sustainability issues of rural credit and saving programs for the poor in Malawi: an action-oriented research project.Washington, DC: IFPRI.

Edet,N; Atairet,E; Nkeme,K; and Sundy,E, U. (2013). Determinants of Loan Repayment: A Study of rural women Fish Traders in Akwa Ibom State, Nigeria. Department of Agricultural Economics and Resource Management, Akwa, Ibom University, Nigeria. British Journal of Economics management and trade. 4(4): 541-550, 2013.

Firafis, H. (2015). Determinants of loan repayment performance: Case study of Harari microfinance institutions. Articles Number: 4137D8C51034ISSN 2141-2154 .Journal of Agricultural Extension and Rural Development. Abo University.

Girma, G. (2008). Determinants of Loan Repayment: The Case of Microfinance Institutions in Gedeo Zone, SNNPRS, Ethiopia. Universal Journal of Accounting and Finance. 6(3): 108-122.

Gujarati,N. (2004). Basic Econometrics, fourth edition.

Haymanot, A; Muluken,M; Qunchera, D; Martin, N,A; Demerew,W,K; and Aynalem, A. (2016).Determinants of Rural Womens' Loan Repayment Performance: The case of Gondar Zuria District, North Gondar, Amahara Regional State.

Ministry of Finance and Economic Development Report,2012.

Ministry of Finance and Economic Development, 2008. Dynamics of Growth and Poverty in Ethiopia (1995/962004/05). Development planning and Research Department, Addis Ababa, Ethiopia. 122p.

Pinaki, B. (1998). Formal and Informal sector interaction in rural credit markets. Journal of development economics, 56: 265-280.

Rotterdam: John Wiley and Sns, Ltd.

Ume, S; Ezeano, C; and Obiekwe, N. (2018). Analysis of Determinants Factors to Loan Repayment among Broiler Farmers in Enugu State, Nigeria. International Journal of Environmental and Agricultural Research. vol (4).

Verbeek, M. (2004). A Guide to Modern Econometrics, Second edition. Erasmus University

Wolday, A .(1999). Improved seed marketing and adoption in Ethiopia. Journal of agricultural economics,3(1): 18-37.

Yamane, T. (1967). Statistics, An Introductory Analysis, $2^{\text {nd }}$ Edition. New work: Harper andRow.

Zelalem,G; Hassen, B; and Jemal, H.(2014). Determinants of Loan Repayment performance of Smallholder farmers: The case of Kalu Distric, South Wollo Zone, Amhara National Regional State Ethiopia. 